Pirineos, 157: 181 a $189, \mathrm{JACA} ; 2002$

\title{
THE HUMAN DIMENSION THAT FAVOURS THE UNNATURAL EXPANSION OF AN EXOTIC UNGULATE (AMMOTRAGUS LERVIA) THROUGHOUT THE IBERIAN PENINSULA
}

\author{
E. Serrano ${ }^{1}$, G. Calabuig ${ }^{2}$, J. Cassinello ${ }^{3} \&$ J. M. Pérez ${ }^{1}$ \\ ${ }^{1}$ Departmento de Biologin Animal, Biologín Vegetal y Ecologa. Unizersidad de Jaén. Paraje Las \\ Lagunillas, s. n. E-23071 Jaén, Spain. E-mail: emmanu@ozu.es \\ ${ }^{2}$ Institufo de Investigación en Recursos Cinegéticos (IREC), CSIC-UCLM-JCCM. Ronda de Toledo s/n. \\ E-13005 Ciudad Real, Spain. \\ ${ }^{3}$ Departamento de Ecología Evolutiva. Museo Nacional de Ciencias Naturales, CSIC. C/José Gutierrez \\ Abrscal, 2. E-28006 Madrid, Spain.
}

\begin{abstract}
Presence of the aondad. Ammotragus lervia, in the Iberim Peninstula is shown, including both free-ranging populations and those in game reserves reported to be currently hosting the species. It has been confirmed that this caprinae is present, with certainty, in 10 Spanish provinces and we can suspect that it is present in three more. There are two factors wich could hove encouraged a rapid expansion of this species through the whole of the Therian Peninsula: (i) it has a great adaptation potential to new environments, and (ii) human transiocations facilitate and accelerate the expansion and colonization processes of the aoudad. The human dimension is discussed as barrier to any polential control programs.
\end{abstract}

RÉSLMEE.- La présence de l'aoudad, Ammotragus lervia, dans la Péninsule ibétique a été noté tant en populations en liberté qu'en réserves de chasse. II a été confirmé que ce caprinae est présent dans 10 provinces ef nous pensons qu' il l'est' egalement dans trois autres. Cette exparsion rapide peut s'expliquer par deux facteurs majeurs, la bonne adapiation potentielle da son nouveau environnement et les introductions ou tratsports humains qui ont facilité le processts de colonisation. Dars ce travail, nous soulignons comment cette dimension humaine peut devenir une barrière importante pour des programmes potentiels de contrôle.

RESLIMEN.- Se describe la presencia de las poblaciones de arrui (Ammotragus lervia) en la Pentinsula Ibërica, tanto en libertad como ias tibicadas ent colos de caza. Se ha confirmado la presencia de este caprino on 10 provincias espafolas y se sospecha que está presente en tres más. Los factores que podrlan expiicar 
la rápida expansión de este ungulado por toda la Pentrusula Iberica son: (i) la gran adaplación potencial a nueoos ambientes y (ii) las traslocaciones humtras que aceleran los procesos de colonización y expansión. En el presente estudio se muestm cómo el fractor humano puede llegar a ser un obstáculo importante a la hora de rleoar a cabo planes de confrol.

Key-words: Ammotragus lervia, biological invasions, exotic ungulate, Iberian Peninsula.

\section{Introduction}

Wildlife management is based on human values since its beginnings as a discipline because wildlife is a resource for people. Its primary goal is to manage interactions between people and wildlife (LEOPOLD, 1933; DECKER et al., 2001). In practice, the human dimensions are an integral component of wildlife management. Mankind has always been somewhat more interested in that which is unusual or exotic in nature. Similarly, hunters often gain more pleasure from hunting an introduced species than they do regarding a local one (GILBERT \& DODDS, 1992). In our study case, both topics converge into a North African caprinae, the aoudad (Ammotragus lervia) the most recent ungulate species officially introduced into the Iberian Peninsula; back in 1970. Such introduction was mediated, mainly, by game interests (FANDOS \& REIG, 1992; CASSINELLO, 1998, 2000), and currently aoudad's trophies may reach very high prices, up to the point that game reserves owners' have an increasing interest on the species. On the other hand, the characteristic large body size of adult males makes this ungulate very attractive for hunters (GRAY, 1985). The enormous potential for dispersion, characteristic of the species (DICKINSON \& SIMPSON; 1980), together with recent new introductions carried out in private reserves, may contribute to a fast increase of its distribution range, due to escapes from broken and/or open fences (SERRANO et al, 2002). Taking into account all of the above mentioned factors, we consider that human dimensions concerning this big game species may become a serious handicap to its effective control.

\section{Material and methods}

From 1999 to 2002, we have compiled information on trophy values and localities where aoudad is offered to be hunted in Spain through specialized 
web sites. This information was complemented by bibliographical reviews and consults made to provincial environmental agencies (namely 'Delegaciones Provinciales de Medio Ambiente') from Valencia, Murcia, Castilla-La Mancha, and Andalucía, as well as to different related sectors: shepherds, hunters, forest rangers, fire managers, and naturalists, biologists and park managers. Finally, we completed the information by means of direct fieldwork carried out during the period 1999-2001. In this survey, no sex, age and group types were considered, we only registered presence or absence. We distinguished between animals included in fenced game reserves and those conforming free-ranging populations.

\section{Results and discussion}

\section{Aoudad distribution}

Currently, the species can be found in thirteen provinces of the Iberian Peninsula, including both private and public game reserves as well as freeranging populations. Seven provinces harbor fenced reserves, (e.g, Granada, Alicante, Valencia, Ciudad Real, Cáceres and Toledo). Regarding the last province we have found bibliographic references (DELIBES, 1986) and Internet announcements which indicate the presence of, at least, one game reserve. In any case, we have not confirmed here if this enclosure is still operative. In other four provinces (Huelva, Cádiz, Córdoba and Jaén) we only suspect the presence of this ungulate in game reserves, because we have received official communications indicating the absence of the species in the respective province, or, at least, the lack of permission to introduce it legally. Nevertheless, different personal communications indicate that the aoudad has been experimentally introduced in certain game enclosures, but up to the moment animals are not yet hunted (Figure 1, symbol ¿?). In five provinces (namely, Jaén, Granada, Almeria, Murcia and Alicante) we can found free-ranging aoudad's populations. The free-ranging population distributed throughout northen Alicante has evolved from a founder group consisting of 49 females and 10 males which escaped from one game enclosure (SERRANO et al., 2002). However the primary source of these and all of the free-ranging animals distributed throughout the remaining three provinces, is the original group which was liberated in the Sierra Espuña Regional Park (Murcia) in 1970's (SERRANO et al., 2002; CASSINELLO et al, 2003). 
PIRINEOS 157
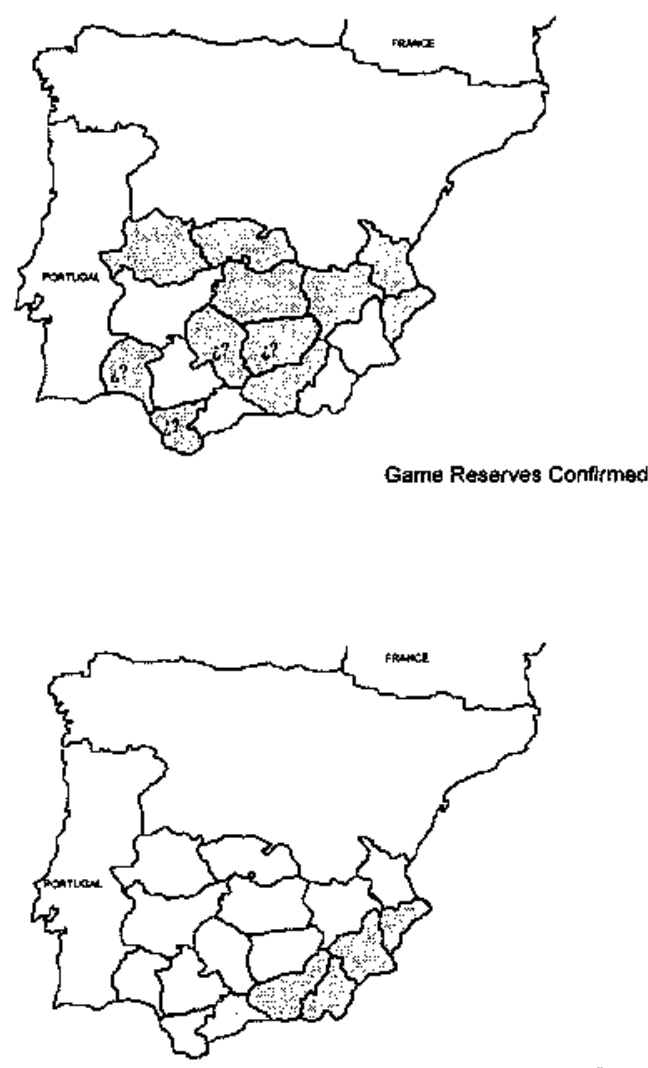

Free-ranging Populations Confirmed

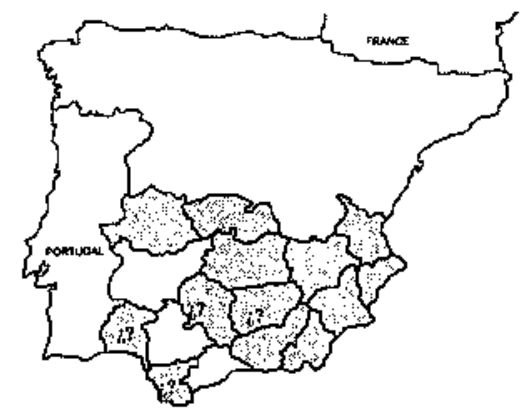

Current Status 2003

Figure 1. Provinces in the Iberian Peninsula where aouadads can be found. 


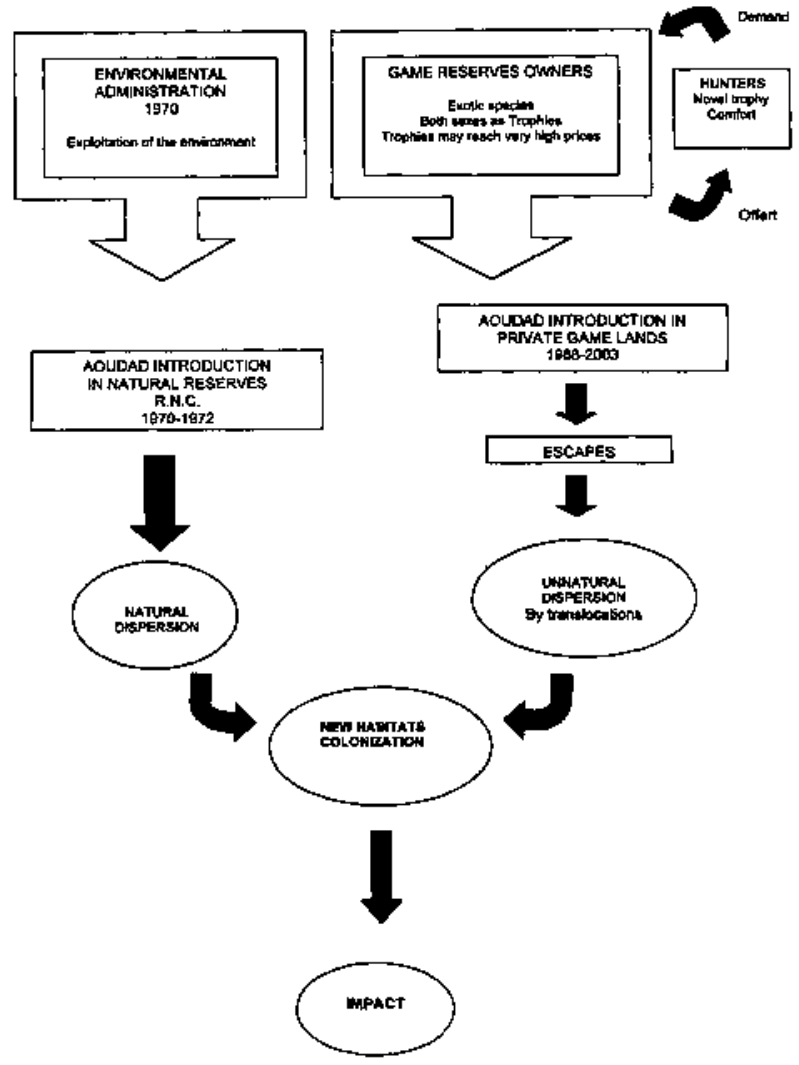

Figure 2. The human dimensions could explain the curnent status of the aoudad (Ammotragus lervia)

The human dimensions influence directly the aoudad distribution

Both natural aoudad dispersion (from escapes) and translocations have their origins on human interests (Figure 2). Nowadays the hunters consider the aoudad as a common game species as there are several private societies that commercialize its hunt in the Peninsula Iberica. Aoudad provides appealing trophies and male body size is impressive (the biggest caprine in the Iberica Peninsula), so that both hunters and reserves owners are particularly interested in it. In January 2002, the Journal of the Spanish Game Federation (Federcaza) published the evaluation standards for aoudad trophies, as a response to the increasing number of animals who were shot during last three years. 
The hunters

As we noted before, humans have special interest in those animals (and organisms, in general) considered as 'exotic' or 'rare'. This fact has allowed multiple translocations involving a number of vertebrate species. Wild ungulates, especially wild caprinae, fall within this trend or phenomenon, and we can find numerous examples worldwide. Regarding the aoudad in Spain, nineteen licences for trophies were awarded by the Reserva Nacional de Caza of the Murcian Regional Government (southeastern Spain) in 2000 (see Dirección General de Medio Natural, unpublished). To harvest these 19 individuals it was necessary to make a selection between a total of 3551 requests (from which 71 came from Spain and the remaining 3480 from other European countries). However other game collectives have conscience that aoudad may become an environmental problem because they have observed competence between this caprine and other local game species.

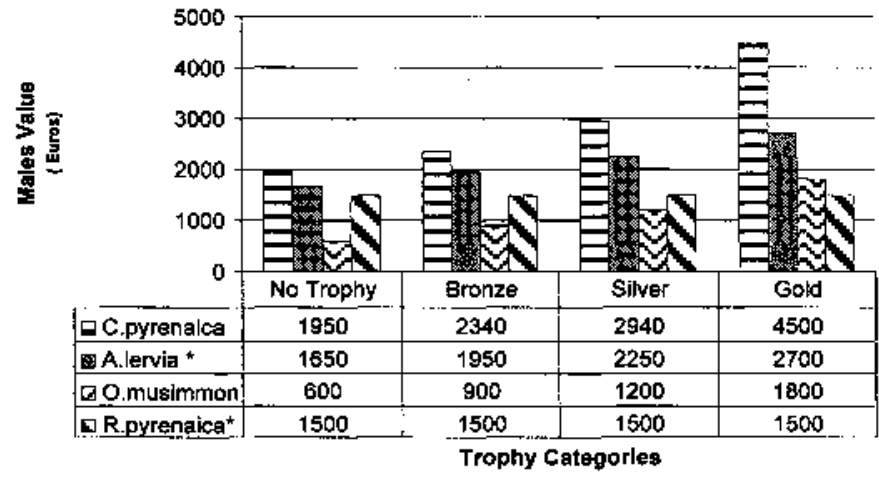

- Both sexes can be hunted

Figure 3. Trophy categories and prices of four Iberian mountain ungulates species.

The game reseroes owners

Due to the obvious commercial benefits, the owners of game reserves are showing increasing interest in this species. Aoudads can be hunted in the Iberian Peninsula throughout the whole year in some private game reserves (http: / /www.Imrecinegetico.com, http:/ /www.cazaylibros.com), whereas in 
public reserves, hunting is only allowed three months a year (from September to November, during the mating season). The advantages of holding aoudads in private game reserves can be summarized in three facts: 1) both male and female are valuable as trophies; 2 ) it is a novel species; and 3) trophies may reach very high prices (http://www.imrecinegetico.com, http://www. cazaylibros.com). Currently aoudad trophy value reaches the second position in the Iberian mountain ungulates trophy ranking (Figure 3).

Table 1. Current status on aoudad of aoudad from different sources.

\begin{tabular}{|c|c|c|c|c|}
\hline Province $E$ & $\begin{array}{c}\text { Provintcial } \\
\text { Environmentat } \\
\text { Agencies }\end{array}$ & $\begin{array}{l}\text { Otr } \\
\text { Study }\end{array}$ & Type & Comment \\
\hline Almería & Presence & Presence & Field prospections & Free ranging populations since 1980 \\
\hline Granada & Absence & Presence & $\begin{array}{l}\text { Field prospections } \\
\text { Personal communication }\end{array}$ & $\begin{array}{l}\text { Two enclosed game reserves } \\
\text { and free ranging populations }\end{array}$ \\
\hline ไаé́n & Absence & Presencente & $\begin{array}{l}\text { Field prospections } \\
\text { Personal communication }\end{array}$ & $\begin{array}{l}\text { Experimental introduction in } \\
\text { one enclosed game reserve }\end{array}$ \\
\hline Córdoba & Absence & Presence & Personal commirication & $\begin{array}{l}\text { Experimental introduction in } \\
\text { one enclosed game reserve }\end{array}$ \\
\hline Málaga & Absence & Absence & - & - \\
\hline Sevilla & Absence & Absence & - & $=$ \\
\hline Cádiz & Absence & Presence & Bibliographic reference & $\begin{array}{l}\text { Experimental introduction in } \\
\text { one enclosed gane reserve }\end{array}$ \\
\hline Huelva & Absence & Presence & Personal communication & $\begin{array}{l}\text { Experimental introduction in } \\
\text { one enclosed game reserve }\end{array}$ \\
\hline Valencia & - & Presence & Web announcement & Two enclosed game reserves \\
\hline Alicante & - & Presence & $\begin{array}{l}\text { Field prospections } \\
\text { Personal communication }\end{array}$ & $\begin{array}{l}\text { Three enclosed game reserves } \\
\text { and free ranging populations. }\end{array}$ \\
\hline Castellon & $=$ & * & - & - \\
\hline Murcia & $=$ & Presence & $\begin{array}{l}\text { Field prospections } \\
\text { and bibliographic references }\end{array}$ & Free ranging population since 1970 \\
\hline Ciudad Real & - & Presence & $\begin{array}{l}\text { Web announcement } \\
\text { and field prospection }\end{array}$ & Four enclosed game reserves \\
\hline Albacete & - & Presence & Web announcement & One enclosed garne reserve \\
\hline Toledo & Absence & Presence & Web announcement & Two enclosed game reserves \\
\hline Guadalajara & Absence & Absence & - & $=$ \\
\hline Cuenca & Absence & Absence & $\cdot$ & $=$ \\
\hline Caceres & - & Presence & Web announcement & One enclosed game reserve \\
\hline
\end{tabular}




\section{The provincial environmental agencies}

We have interviewed the environmental agencies in 18 provinces where we suspected or had the certainty of the presence of this ungulate (Table 1). In general we have noted that the environmental agencies have conscience that the aoudad is an exotic vertebrate and therefore introducing this species into new habitats may imply a negative impact on native flora and fauna. We have received a response from 11 consults $(61.1 \%$ ). In six of these 11 cases, our information about aoudad distribution did not fit the 'oficial' one (Table 1). Five of them contained the same information than did our study and only one (that coming from Almeria province) contained detailed information about recent control efforts and current status in the region.

\section{Perspectives and recommendations}

Ignoring the potential impact which may produce the aoudad, together with the increasing economic interest derived from harvesting this caprinae species, may be considered as two main factors favoring a fast increase of its distribution range throughout the Iberian Peninsula. Within this trend or context, eventual management programs for the species (e. g. control programs) will become more and more difficult with time. In our opinion the complete eradication may be a difficult option, from a technical point of view. Moreover, it may derive or become a social conflict. This fact is well illustrated from the current situation in the Caldera de Taburiente National Park (Canary Islands), where aoudad was also introduced. The direction and staff of the national park proposed the total eradication within the protected area several years ago. At the same time, hunters ate favoring the dispersion of this caprinae in game reserves outside of the National Park. Moreover, out of the park boundaries, supplementary food and water are provided to aoudads. Despite all this difficulties, a new point of view could decrease the dispersion of this exotic ungulate, that is to officially consider its presence as a biological invasion and therefore to start a consequent management. On the other hand, if we try to control this species, we must firstly to gather basic information about its biology and ecology. This is another problem, because very little is known about free-ranging aoudads. It would be also desirable to design a global strategy between the regions which harbor the species and to decide in which circumstances may be advisable a maximum effort to its effective control, and/or if there is any region which could allow a sustainable management (harvest) of the species. Obviously, in such cases, we must to consider infrastructures (fences) providing maximum security (probability of escapes close to 0). 
THE HUMAN DIMENSIONS ARE FAVOURING THE UNNATURAL EXPANSION OF AN EXOTIC UNGULATE

\section{References}

CASSINELLO, J. (1998). Ammotragus lervia: a review on systematics, biology, ecology and distribution. Annales Zoologici Fennici, 35: 149-162.

CASSINELLO, J. (2000). Ammotragus free-ranging population in the south east of Spain: a necessary first account. Biodiversity and Conservation, 9: 887-900.

CASSINELlO, J.; SERRANO, E.; CALABUIG, G. \& PÉREZ, J. M. (2003). Evidence of Ammotragus freely expansion in the south of Spain: ecological and conservational concerns Biodiversity and Conservation. (In press)

CAZA Y LIBROS: Recechos. http://www.Cazaylibros.com/recechos $/$ [Revised: 21 May. 2002]

DECKER, D. J.; BROWN, T. L. \& SIEMER, W. F. (2001). Evolution of PeopleWildlife Relations. In DECKER, D. J; BROWN, T. L. \& SIEMER (Eds.): Human dimensions of Wildlife mantagement in North America. The Wildlife Society, Bethesda: 3-22.

DELIBES, M. (1986). Ammotragus leroia (Pallas 1777), Mänenschaf. In: NIETHAMMER, G. (Ed.), Handbuch der Säugetiere Europas: 423-431.

DICKINSON, T. G. \& SIMPSON, C. D. (1980). Home range movements, and topographic selection of Barbary sheep in the Guadalupe Mountains, New Mexico. In SIMPSON, C. D. (Ed.). Symposium on ecology and management of Barbary sheep. Texas Tech Univ. Press, Lubbock: 78-86.

DIRECCIÓN GENERAL DEL MEDIO NATURAL (2002). Región de Murcia. Informe de la Reserva Nacional de Caza de Sierra Espuña. (Unpublished)

FANDOS, P. \& REIG, S. (1992). Problems associated with mouflon and Barbary sheep introductions in Spain. In BOBEK, B.; PERZANOWSKI, K. \& REGELIN, W. (Eds.). Global Trends in Wildlife Management. Trans. 18th IUGB Congress, Krakow 1987. Swiat Press, Krakow-Warszawa: 139-140.

GILBERT, F. F. \& DODSS, D. G. (1992). The philosophy and practice of Wildlife Management. ${ }^{\text {nd }}$ Ed. Krieger Publishing Company, Florida: 313 pp.

GRAY, G.G. (1985). Status and distribution of Ammotragus lervia: a worldwide review. In HOEFS, M. (Ed.), Wild sheep. Distribution, abundance, management and conservation of the sheep of the world and closely related mountain ungulates. Northern Wild Sheep and Goat Council, Whitehouse, Yukon, Canada: 95-126.

IMRECINEGETICO: Recechos. http://www.imrecinegetico.com/recechos/ [Revised: 21 May. 2002]

LEOPOLD, A. (1933). Game Management. Charles Scribner's Sons, New York: 481 pp.

SERRANO, E; CALABUIG, G.; CASSINELLO, J; GRANADOS, J. E. \& PÉREZ, J. M. (2002). Chorology of the Aoudad (Ammotragus lervia, Pallas 1777) in Southern Spain. Galemys, 14(1):17-29. (In Spanish with English summary) 